\title{
TANGGUNG JAWAB NOTARIS TERHADAP AKTA YANG DIUBAH SECARA SEPIHAK (CONTOH KASUS: PUTUSAN MAHKAMAH AGUNG NOMOR 146/PDT/2018/PT.BDG.)
}

\author{
Michelle Starla Ongko \\ (Tarumanagara University Faculty of Law Undergraduate Program Students) \\ (Email: michellestarla31@gmail.com)
}

\section{Dr. Ariawan Gunadi, S.H, M.H. \\ (Corresponding Author)}

(Lecturer at the Faculty of Law, Tarumanagara University. Obtained a Bachelor of Law in the Faculty of Law Tarumanagara University, Master of Law at the Faculty of Law, Jakarta Islamic University, Doctor of Law at the Faculty of Law, University of Indonesia.)

(Email: ariawangun@gmail.com)

\begin{abstract}
:
Renvoi is the changes that was made before the deed was signed by the parties. There is quite a difference between a change in the deed, which are made before signed and the change after signed. Whereas if the change was made after signed, the change must be made in the presence of the parties, witnesses, and the public notary, reported in an official statement of the event and give no regarding the matter to the original copy of the deed with notification of the date and number of the correction. If a Notary does not do as provided in the renvoi procedure, it may result in the deed being considered inauthentic. And could result in one of the party to suffer a loss in the foreseeable future and it could serves as a legal basis to claim compensation, damages plus interests and to be put on the public notary's responsibility. Based on the example of the present case in Supreme Court Decree No. 146 / PDT / 2018 / PT.BDG, in the making of a rent-to-hire deed, there is a difference between the original copy of the deed which are not similar with the copies that are given to the respective parties. The original copy of the deed is full of correction scribbles, replacements, inserts, additions, and overlays, which are definitely not typing mistakes. Thus, the public notary has violated Article 48 of the Public Notary Act No. 2 of 2014.
\end{abstract}

Keywords: Public Notary, Authentic Deeds, Public Notary's Responsibility.

\section{PENDAHULUAN}

\section{A. Latar Belakang}

Indonesia adalah negara hukum di mana negara ini menempatkan hukum sebagai posisi tertinggi dalam pemerintahannya. Undang-undang ini mengatur semua hubungan hukum antara individu dan individu, individu dan masyarakat 
dan individu dan pemerintah. ${ }^{1}$ Selain itu hukum juga merupakan perlindungan bagi kepentingan manusia. ${ }^{2}$ Karena pentingnya arti hukum bagi negara ini, profesi hukum juga sangat penting untuk melaksanakan, mengawasi, dan mengatur hukum. Profesi hukum ini menyediakan layanan di bidang hukum. Berbagai profesi hukum di Indonesia, salah satunya adalah profesi Notaris.

Dalam menjalankan profesinya sebagai Notaris, Notaris diatur oleh hukum dalam memberikan layanan kepada masyarakat dengan harapan memberikan layanan kepada masyarakat yang diberikan oleh Notaris kepada kliennya. Selain itu, seseorang yang berprofesi sebagai Notaris diharapkan berperilaku sesuai aturan yang berlaku. Ini adalah hal yang sangat penting karena seorang Notaris diharapkan dapat menjalankan tugas kantornya tidak hanya untuk memprioritaskan dan memprioritaskan kepentingan pribadinya tetapi seorang Notaris harus memprioritaskan kepentingan masyarakat dan berkewajiban untuk menjamin bahwa akta tersebut dibuat itu benar. Oleh karena itu, Notaris dituntut untuk memiliki sikap yang adil, jujur, dan transparan untuk memastikan implementasi tujuan dan kewajiban semua pihak yang terlibat baik secara langsung terkait dengan pembuatan akta otentik atau tidak secara langsung terkait dengan pembuatan autentik perbuatan. Notaris harus menjunjung tinggi kode etik dari posisi Notaris di Indonesia melaksanakan tugas dari posisinya. Karena tanpa cengkeraman yang kuat pada Kode Etik Notaris, seorang Notaris Publik akan kehilangan martabat profesionalisme dan akan kehilangan kepercayaan masyarakat sehingga jika martabat profesionalisme dan kepercayaan dari masyarakat telah hilang, orang tersebut dapat dikatakan menjadi tidak layak untuk menjalankan tugasnya sebagai Notaris.

Akta otentik yang berisi semua akta, perjanjian, dan ketentuan dibuat oleh notaris yang diberi wewenang atas perintah yang diberikan oleh aturan umum atau atas permintaan para pihak yang membuat akta.

2 Mochtar Kusumaatmadja, Pengantar Ilmu Hukum Suatu Pengenalan Pertama Ruang Lingkup Berlakunya Ilmu Hukum, (Bandung: Alumni, 2000), 43.

${ }^{2}$ Sudikno Mertokusumo, Mengenal Hukum Suatu Pengantar, (Yogyakarta: Liberty, 2003), 21. 
Definisi Notaris diatur dalam Undang-Undang Posisi Notaris Pasal 1 angka 1 yang menjelaskan bahwa "Notaris adalah Penjabat Penulis Umum. Yang berwenang membuat akta otentik dan memiliki otoritas lain sebagaimana dimaksud dalam undang-undang." ${ }^{3}$

Akta otentik dibuat dengan memasukkan semua kebenaran material yang sesuai dengan apa yang diberikan oleh klien yang menghadap notaris yang dipercaya dan telah diberi wewenang oleh pihak-pihak yang menghadapi. Meskipun pihak-pihak yang telah diberi wewenang disahkan, seorang Notari masih memiliki kewajiban untuk memastikan bahwa segala sesuatu yang telah terkandung dalam akta yang dibuatnya telah dipahami dan sesuai dengan keinginan pihak-pihak yang diinginkan dengan membacanya sehingga isi akta membuat jelas isi akta yang dibuat dan memberikan akses ke informasi termasuk akses ke hukum dan peraturan yang relevan bagi para pihak dalam akta tersebut.

Dengan demikian, para pihak dapat menentukan secara bebas untuk menyetujui atau tidak isi akta yang akan ditandatangani. Seseorang yang bekerja sebagai Notaris sebagai profesi hukum tidak berarti bahwa Notaris tidak akan diseret atau disalahkan dalam undang-undang tentang akta dibuat untuk pihakpihak yang menghadapinya dan memberikan wewenang untuk membuat akta karena terkait dengan profesi pekerjaan dalam praktiknya ditemukan bahwa sering kali akta sebagai produk Notaris sedang dipermasalahkan oleh para pihak kepada publik notaris atau pihak ketiga lainnya.

Tanggung jawab itu ditentukan oleh sifat pelanggaran dan akibat hukum yang ditimbulkannya. Secara umum, kewajiban yang biasa dikenakan pada notaris adalah tanggung jawab pidana, administratif dan sipil. Menentukan keberadaan pertanggungjawaban perdata atau pidana yang dilakukan oleh Notaris harus memenuhi tiga syarat, yaitu harus ada tindakan notaris yang dapat dihukum yang unsur-unsurnya dirumuskan secara eksplisit oleh Undang-Undang. Sehingga pada

\footnotetext{
${ }^{3}$ Tan Thong Kie, Buku I Studi Notariat, Beberapa Mata Pelajaran dan Serba-serbi Praktik Notaris, Ichtiar Baru Van Hoeve, (Jakarta: PT Ichtiar Baru Van Hoeve, 2000), 162.
} 
Volume 2 Nomor 2, Desember 2019 E-ISSN : 2655-7347

dasarnya setiap bentuk pelanggaran atau kelalaian yang dilakukan oleh Notaris selalu mengandung sifat yang melanggar hukum dalam bertindak.

Notaris harus siap menghadapi jika sewaktu-waktu dibuat pihak yang terlibat dalam kasus hukum, yang merupakan hasil dari akta yang dibuatnya. Sehingga dalam menjalankan tugas kantornya tidak dapat dipungkiri lagi saat ini cukup banyak masalah hukum yang timbul dan terjadi akibat perilaku seorang notaris yang tidak profesional dan berpihak pada salah satu pihak atas perbuatan yang dilakukannya.

Sebagai salah satu contoh kasus yang penulis adopsi, yaitu dalam keputusan nomor 146 / PDT / 2018 / PT.BDG, dalam membuat akta sewa ruko (ruko) sewa antara JuJu Andriyani dengan PT Indomarco Prismatama sebelum Notaris Umang Retno Ayu Melasari, SH, ada permintaan untuk membuka MINUTA AKTA Authentic No. 31.

Namun, dalam persidangan, Salinan Risalah Akta tidak terlihat yang tidak terdengar sama dengan Salinan Akta. Dalam Akta Minutta ternyata penuh coretan, belokan, sisipan, tambahan, dan seperti tumpang tindih apa pun, yang bukan salah ketik. Fakta hukum yang mewakili PT Indomarco Prismatama tidak disajikan pada penandatanganan Akta Otentik No. 31 oleh Notaris Umang Retno Ayu Melasari, S.H. (ini dibuktikan dengan tidak adanya dokumen dan sidik jari yang melekat pada Risalah Akta).

Dalam Penutupan Akta Notaris No. 31 Umang Retno Ayu Melasari, SH telah menulis frasa "dilakukan tanpa perubahan apa pun" tidak boleh ada perubahan dalam Risalah Akta otentik No. 31, tetapi pada kenyataannya Minuta Akta memiliki banyak perubahan, dalam Akta otentik No. 31 ditulis. Namun, ada ungkapan "diberikan sebagai salinan yang sama". Salinan Akta Otentik harus persis sama dengan Risalah Akta, tetapi pada kenyataannya itu tidak terdengar sama.

Dengan demikian Notaris Umang Retno Ayu Melasari, S.H melanggar Pasal 48 Undang-Undang Nomor 2 Tahun 2014 tentang Kedudukan Notaris yaitu isi akta yang dilarang untuk diubah dengan:

1. Diganti; 
Volume 2 Nomor 2, Desember 2019

E-ISSN : 2655-7347

2. Plus;

3. Dicoret;

4. Dimasukkan;

5. Dihapus; dan / atau

6. Ditulis.

Bahwa kepalsuan dari Akta Notaris adalah adanya Kepalsuan Intelektual yang terdiri dari:

a) Pemohon memberikan informasi yang salah dalam akta (isi akta)

b) Notaris memberikan informasi yang salah kepada kepala Akta, pembanding, (identitas) dan akhir akta

c) Notaris mengubah, menambah atau menghapus pernyataan para pihak (di luar prosedur konvoi yang diatur dalam Hukum Posisi Notaris)

d) Ada kondisi hukum aktual, yaitu; adanya kondisi hukum yang sebenarnya adalah tanda tangan para pihak, notaris dan saksi

e) Ada suatu kondisi hukum aktual salinan akta, akta grosse dan atau akta kutipan sehingga dengan demikian Akta Sewa Guna No. 31.

Berdasarkan uraian latar belakang di atas, penulis tertarik untuk membuat jurnal dengan judul: "TANGGUNG JAWAB NOTARIS TERHADAP AKTA YANG DIUBAH SECARA SEPIHAK (CONTOH KASUS: PUTUSAN MAHKAMAH AGUNG NOMOR 146/PDT/2018/PT.BDG.)"

\section{B. Permasalahan}

Berdasarkan uraian latar belakang di atas, masalah yang peneliti ingin analisis adalah sebagai berikut:

1. Bagaimana tanggung jawab notaris atas akta yang diubah secara sepihak berdasarkan keputusan Mahkamah Agung Nomor 146 / PDT / 2018 / PT.BDG?

2. Bagaimana validitas sertifikat yang telah diubah secara sepihak?

\section{Metode Penelitian}


Metode penelitian hukum adalah proses menemukan aturan hukum, prinsip hukum, dan doktrin hukum untuk mengatasi masalah hukum yang akan dihadapi. Metode penelitian adalah elemen absolut yang harus ada dan berfungsi untuk mengembangkan ilmu pengetahuan. ${ }^{4}$

\section{PEMBAHASAN}

\section{A. Bagaimana tanggung jawab notaris atas akta yang diamandemen secara sepihak berdasarkan putusan Mahkamah Agung Nomor: 146 / PDT / 2018 / PT.BDG?}

Pejabat publik notaris yang berwenang membuat akta otentik dapat dimintai tanggung jawab atas tindakannya sehubungan dengan pekerjaannya dalam membuat akta. Kewajiban Notaris didasarkan pada peraturan Kantor Notaris (UUJN).

Notaris diberi kuasa khusus dalam membuat surat ikatan berdasarkan Pasal 15 Undang-Undang Nomor 30 Tahun 2004 tentang Kedudukan Notaris, yaitu, Notaris diberi wewenang untuk membuat surat ikatan otentik dalam bidang kuasa yang telah ditentukan sebelumnya mengenai semua tindakan, perjanjian, dan ketentuan yang dibutuhkan oleh peraturan perundang-undangan undangan dan / atau apa yang dimaksudkan oleh pihak-pihak yang bersangkutan untuk dinyatakan dalam surat ikatan otentik selagi akta itu tidak juga diberikan atau dikecualikan kepada pegawai lain atau yang lain yang ditentukan oleh undang-undang.

Notaris juga diberi kuasa untuk menjamin kepastian tarikh pembuatan surat ikatan. Tarikh yang dimaksudkan adalah tarikh surat ikatan itu dipasang. Pihak berkuasa lain yang diberikan kepada notari adalah kuasa untuk menyelamatkan surat ikatan, memberikan salinan dan mengutip surat ikatan dan memberikan surat ikatan grossa yang merupakan salinan akta untuk mengiktiraf hutang dengan memiliki kepala surat ikatan yang berbunyi "BAGI KANAN KEADILAN DI BAWAH TUHAN YANG MAHA ESA" yang memiliki kuasa pelaksanaan seperti keputusan hakim. Notari hanya boleh memberi, menunjukkan kandungan surat ikatan, surat ikatan kasar, salinan akta itu kepada pihak-pihak yang secara

\footnotetext{
${ }^{4}$ Soerjono Soekanto, Pengantar Penelitian Hukum, (Jakarta: UI Press, 1981), 7.
} 
Volume 2 Nomor 2, Desember 2019

E-ISSN : 2655-7347

langsung berminat dengan surat ikatan itu kecuali undang-undang menetapkan sebaliknya.

Akta yang dibuat oleh Notaris Umang Retno, S.H. ada cacat di mana akta perjanjian sewa banyak coretan dan penyisipan, menurut pendapat penulis Notaris Umang Retno, S.H. melanggar UUJN dalam pasal 48, yaitu isi akta dilarang diubah dengan:

1. Diganti

2. Plus

3. Dicoret

4. Dimasukkan

5. Dihapus; dan / atau

6. Ditulis.

Menurut pertimbangan Hakim tentang putusan Nomor: 146 / PDT. / 2018 / PT.BDG. Notaris Umang Retno, S.H. telah terbukti mengubah akta secara sepihak tanpa sepengetahuan Juju Andriyani, oleh karenanya Notaris Umang Retno, S.H. terbukti melanggar UUJN dalam Pasal 48 karena mencoret akta dan memasukkan akta perjanjian.

Karena itu, Notaris Umang Retno, S.H. wajib bertanggung jawab sesuai dengan UUJN, yaitu Pasal 48 ayat 3 (tiga), yang merupakan akta hanya memiliki kekuatan pembuktian sebagai akta di bawah tangan dan dapat menjadi alasan bagi pihak yang menderita kerugian untuk menuntut kompensasi, kompensasi, dan bunga untuk notaris. Selanjutnya menurut Pasal 51 UUJN menyatakan:

1. Notaris berwenang untuk memperbaiki kesalahan tertulis atau tipografi terkandung dalam risalah akta yang ditandatangani.

2. Koreksi sebagaimana dimaksud pada ayat (1) dilakukan dalam kehadiran penyadap, saksi dan Notaris sebagaimana diuraikan dalam pejabat melaporkan dan memberikan catatan pada notulen asli akta oleh menyebutkan tanggal dan nomor laporan resmi yang dikoreksi.

3. Salinan laporan resmi sebagaimana dimaksud pada ayat 2 (dua) menghasilkan akta yang hanya memiliki kekuatan pembuktian 
Volume 2 Nomor 2, Desember 2019 E-ISSN : 2655-7347

sebagai akta di bawah tangan dan dapat berupa alasan partai menderita kerugian untuk meminta kompensasi, kompensasi, dan bunga kepada notaris.

Jadi kesimpulannya adalah pelanggaran yang dilakukan oleh Notaris Umang Retno, S.H. yang mengakibatkan kerugian bagi Juju Andriyani di mana akta sewa secara hukum cacat, sehingga sesuai untuk Notaris Umang Retno, S.H.

bertanggung jawab sesuai dengan ketentuan dalam pasal 48 ayat 3 (tiga) dan Pasal 51 UUJN.

\section{B. Apa konsekuensi hukum dari Akta yang dibuat secara sepihak?}

Dalam putusan Mahkamah Agung Nomor 146 / PDT / 2018 / PT.BDG, Penggugat bernama Juju Andriyani, ditandatangani oleh Notaris Umang Retno Ayu Melasari, S.H dan tidak dihadiri oleh perwakilan PT. Indomarco Prismatama. Tidak adanya perwakilan dari PT. Indomarco Prismatama mengakibatkan Ibu Juju Andriyani tidak mengetahui bahwa ketika menandatangani akta tersebut, perwakilan dari PT. Indomarco Prismatama tidak membawa surat kuasa, dan Notaris Umang Retno Ayu Melasari, S.H yang mengetahui hal ini masih ingin terus menandatangani akta dan menulis komparatif dari perwakilan PT. Indomarco Prismatama sebagai pemakan dalam kedudukannya berdasarkan surat kuasa. Ketika ditemukan oleh Ibu Juju Andriyani, telah berlalu sekitar 2 minggu dan Notaris Umang Retno Ayu Melasari, S.H.

Akta yang dibuat oleh notaris dalam Putusan Pengadilan Tinggi Bandung nomor 146 / Pdt / 2018 / PT.Bdg (selanjutnya disebut "keputusan PT") adalah akta yang membahas penyewaan, yang terkenal Umang Retno Ayu Melasari, S.H.

Notaris Umang Retno Ayu Melasari, S.H tidak dianggap telah melanggar ketentuan ini karena penggugat sedang berurusan dengan notaris. Setelah mengetahui bahwa akta sewa dibuat oleh notaris yang berwenang, ia harus melihat validitas akta yang harus dilihat terlebih dahulu melalui perspektif kondisi hukum perjanjian. Ketentuan untuk validitas perjanjian yang diatur dalam KUH Perdata, yaitu: 
1. Setuju dengan mereka yang berkomitmen

Transaksi sewa yang dilakukan oleh Ibu Juju Andriyani dan PT. Indomarco Prismatama menunjukkan bahwa ada kesepakatan bersama atas barang-barang dalam bentuk toko milik Ny. Juju Andriyani dan harga Rp320.000.000,00 (tiga ratus dua puluh juta rupiah) untuk disewakan selama 4 (empat) tahun. Perjanjian sewa ini termasuk dalam perjanjian konsensual di mana perjanjian ini dianggap sah dan mengikat para pihak ketika kesepakatan dicapai antara para pihak mengenai unsur-unsur utama perjanjian ini, yaitu barang dan harga. Akta perjanjian sewa No. 31 dibuat berdasarkan perjanjian antara Ibu Juju Andriyani dan PT. Indomarco Prismatama. Sesuai dengan ketentuan hukum perjanjian sewa, akta tersebut berlaku sebagai hukum untuk Ms. Juju Andriyani dan PT. Indomarco Prismatama, ini sejalan dengan ketentuan dalam Pasal 1338 KUH Perdata yang berbunyi:

"Tous les traités conclus légalement s'appliquent en tant que loi à ceux qui les concluent. Un accord ne peut être retiré que par accord des deux parties, ou pour des raisons qui sont jugées suffisantes par la loi. Un accord doit être exécuté de bonne foi"

Namun, dalam hal ini ada pertanyaan tentang kesepakatan para pihak karena penemuan akta renvoi dalam bentuk grafiti, belokan, sisipan dan tumpang tindih tidak disebabkan oleh kesalahan dalam pengetikan dan juga masalah ini tidak diketahui oleh penggugat. Masalah dengan renvoi ini tidak akan dijelaskan dalam sub-bab ini tetapi akan dijelaskan pada sub-bab selanjutnya.

2. Mahir membuat kesepakatan

PT. Indomarco Prismatama adalah perusahaan perseroan terbatas sehingga untuk melakukan tindakan hukum harus diwakili oleh seorang direktur atau dewan komisaris atau juga dapat memberikan kuasa kepada karyawan yang memenuhi persyaratan yang 
ditentukan dalam anggaran dasar perusahaan. Dalam hal ini, PT. Indomarco Prismatama diwakili oleh Muhamad Agus Noviyanto yang kemudian diberi kuasa oleh presiden direktur perusahaan.

Oleh karena itu, sebagai penerima surat kuasa, Muhammad Agus Noviyanto memiliki wewenang untuk mewakili perusahaan selama ia memiliki kuasa hukum dari perusahaan, tetapi wewenangnya dipertanyakan karena penundaan tanggal surat kuasa diberikan dari perusahaan kepadanya, yang menimbulkan masalah hukum atas wewenangnya untuk mewakili perusahaan.

Diskusi mengenai wewenang Muhammad Agus Noviyanto akan dibahas kemudian setelah diskusi singkat tentang persyaratan hukum perjanjian sewa. Suatu perjanjian harus terkait dengan halhal yang telah ditentukan oleh peraturan tertentu, jelas dan dapat ditentukan jenisnya dan merupakan objek atau objek yang dapat diperdagangkan sebagaimana diatur dalam KUH Perdata mengenai kondisi hukum suatu perjanjian. Dalam perjanjian sewa yang disebut sebagai objek perjanjian adalah bagaimana objek disewakan dan harga. Di sini yang dimaksud adalah dalam bentuk Bangunan Ruko (Ruko) dengan ukuran $187 \mathrm{~m} 2$, yang berdiri di atas tanah seluas $2.230 \mathrm{~m} 2$ sebagaimana dicatat dalam Sertifikat Kepemilikan No. 97, Cileungsi, Bogor atas nama Juju Andryani, yang dikenal dan berlokasi di Jalan Camat Enjan No. 18 A, Rt.002 RW.016 Kelurahan Cileungsi, Kecamatan Cileungsi Kabupaten Bogor, Kp Bpm.

Harga adalah biaya sewa yang harus dibayar oleh PT. Indomarco Prismatama untuk Ibu Juju Andriyani untuk sewa dari objek sewa, yaitu rumah kantor atau yang biasa disebut sebagai ruko selama empat tahun, senilai Rp 320,000,000.00 (320.000.000 rupiah). Kemudian apa yang dimaksud dengan "hal-hal tertentu" dalam hal validitas perjanjian ini terpenuhi. 
Volume 2 Nomor 2, Desember 2019 E-ISSN : 2655-7347

3. Penyebab yang sah

Suatu perjanjian harus dibuat untuk alasan atau tujuan tertentu yang harus sesuai dengan hukum dan peraturan, tidak bertentangan dengan prinsip kesopanan dan aturan ketertiban umum. Perjanjian yang tidak memiliki penyebab tertentu (causa / oorzaak) dapat mengakibatkan perjanjian menjadi tanpa kekuatan hukum. Masalah dalam hal ini adalah bahwa dalam hal ini "Akta Sewa Guna Usaha" kita dapat melihat dan mengetahui bahwa perjanjian yang dibuat antara Ny. Juju Andriyani dan PT. Indomarco Prismatama adalah perjanjian tentang perjanjian sewa.

Perjanjian sewa ini sendiri merupakan salah satu perjanjian yang diatur dalam KUH Perdata sehingga termasuk dalam perjanjian Bamaama yang kemudian tidak bertentangan dengan peraturan yang ada dalam hukum, ketertiban umum dan kesopanan. Adanya prinsip kebebasan kontrak dalam membuat perjanjian tidak dapat menyebabkan perbedaan dalam pengaturan dalam setiap akta sewa yang dianggap ilegal. Salah satu elemen yang dapat diatur secara bebas oleh para pihak dalam sewa adalah harga sehingga harga sewa tidak harus sama.

Masalah dalam kasus ini adalah tentang validitas suatu perjanjian ketika satu pihak menggunakan surat kuasa. PT. Indomarco Prismatama adalah badan hukum dalam bentuk perusahaan sehingga mampu melakukan kegiatan sewa dengan pihak lain selama memenuhi ketentuan dalam undang-undang dan anggaran dasar perusahaan. Untuk melakukan kegiatan leasing dengan Ibu Juju Andriyani, Muhamad Agus Noviyanto (kuasa) mewakili PT. Indomarco Prismatama juga dewasa, cukup tua dan tidak mampu sehingga penerima otomatis surat kuasa ini adalah subjek hukum yang cakap mewakili PT. Indomarco Prismatama. 
Volume 2 Nomor 2, Desember 2019

E-ISSN : 2655-7347

Setelah menyelesaikan kemahiran orang yang berwenang dari PT. Indomarco Prismatama, hal selanjutnya yang harus dipertimbangkan adalah wewenang kuasa dalam membuat akta sewa di hadapan Notaris Umang Retno Ayu Melasari, S.H. Agar orang yang berwenang berwenang untuk mewakili sebuah perusahaan, surat kuasa harus diberikan kepada surat kuasa sebelum pelaksanaan akta dan segala sesuatu yang berkaitan dengan pengelolaan sewa dalam kasus ini. Surat kuasa harus berisi otorisasi dari presiden direktur perusahaan dan dalam posisinya, kepada penerima surat kuasa dan harus dengan jelas menggambarkan identitas surat kuasa.

Kuasa wakil juga mesti menyatakan dengan jelas apa-apa tindakan yang boleh dilakukan oleh penerima kuasa wakil dalam hal ini menerima kuasa wakil untuk mengurus / menandatangani Perjanjian Sewa, termasuk membuat pembayaran sewa dan menerima tanda pembayaran atas objek pajakan. Walau bagaimanapun, dalam hal ini, Notaris Umang Retno Ayu Melasari, S.H mengajak seorang pengacara dari Cik Juju Andriyani untuk menandatangani surat ikatan itu, walaupun pengacara itu belum tersedia. Ini tentunya bercanggah dengan peraturan yang terkandung dalam undang-undang kerana Notaris Umang Retno Ayu Melasari, SH membuat surat ikatan dan menandatangani akta itu dengan seorang penulis yang tidak sah dan menyatakan kepada taper yang mengetuk mempunyai wewenang berdasarkan kekuasaan. dia tidak mempunyai. pada masa itu.

Perkara 47 ayat (1) UUJN menyatakan bahwa suatu surat kuasa yang sahih atau surat lain yang membentuk dasar wewenang untuk membuat Surat Ikatan yang dikeluarkan dalam bentuk asal atau surat kuasa di bawah tangan harus dilampirkan pada Minutes of the Act. Dalam hal ini, dapat dilihat bahwa hampir 1 (satu) bulan setelah surat ikatan ditandatangani oleh Notaris Umang Retno Ayu Melasari, S.H, kepada Puan Juju Andriyani bahwa kuasa pengacara belum turun. Melalui pernyataan Notaris Umang Retno Ayu Melasari, S.H, kuasa surat tidak disertakan dengan akta notaris hingga 27 Oktober 2016, walaupun akta notari itu telah dibuat mulai 29 September 2016. 
Volume 2 Nomor 2, Desember 2019

E-ISSN : 2655-7347

Ada kemungkinan bahwa kekuatan yang diberikan kepada kuasa dibuat secara lisan, dengan mengingat bahwa kekuatan pengacara diketahui secara lisan. Tetapi untuk melakukan tindakan hukum di depan seorang notaris, tentu saja, notaris harus meminta bukti surat kuasa dalam bentuk surat kuasa. Kesulitan membuktikan pemberian kuasa verbal mengakibatkan tidak adanya bukti dari otoritas kuasa, sehingga pada akhirnya pembuktian harus dilakukan dengan memberikan bukti tertulis dalam bentuk surat kuasa.

Ketidakmampuan untuk membuktikan juga mengakibatkan penerima surat kuasa tidak memiliki wewenang atas penyusunan sewa. Ketidakmampuan Ms. Juju Andriyani melanggar ketentuan subyektif dari perjanjian yang memiliki efek perjanjian dapat dibatalkan. Yang dimaksud dengan tidak dapat dibatalkan adalah jika pembatalan tidak diminta ke Pengadilan maka perjanjian akan tetap mengikat para pihak.

Dalam hal ini, Ibu Juju Andriyani menggugat PT. Indomarco Prismatama dan Notaris Umang Retno Ayu Melasari, S.H dengan alasan bahwa PT. Indomarco Prismatama untuk penandatanganan akta sewa. Sebagai konsekuensi dari pembatalan perjanjian, tidak ada pihak yang dapat dirugikan atau kembali ke keadaan semula.

Komparasi itu menggambarkan pihak-pihak sehingga bisa dikatakan perbandingan itu merupakan elemen yang sangat penting dalam akta. Terjadinya kesalahan Notaris Umang Retno Ayu Melasari, S.H sebagai notaris termasuk dalam perbandingan terjadi ketika Notaris Umang Retno Ayu Melasari, S.H tidak menjamin kewenangan PT. Indomarco Prismatama ketika dihadapkan dengan memastikan adanya Surat Kuasa yang menjadi dasar bagi PT. Indomarco Prismatama hadir di hadapannya.

Selain itu, PT. Indomarco Prismatama juga melakukan kesalahan dengan tidak memberikan surat kuasa sebelum menandatangani akta. Mengingat bahwa PT. Indomarco Prismatama adalah perusahaan besar yang sering melakukan 
perbuatan sehingga Notaris Umang Retno Ayu Melasari, S.H dapat dikatakan memiliki pengetahuan tentang kondisi untuk menghadapi dan membuat perjanjian di hadapan notaris. Keberadaan unsur kesalahan notaris dalam membuat akta sewa dapat dikatakan sebagai tindakan ilegal oleh Notaris Umang Retno Ayu Melasari, S.H sebagai notaris.

Akta notaris Umang Retno Ayu Melasari, S.H dikatakan sebagai perbuatan melawan hukum karena mengandung kesalahan sebagaimana dimaksud dalam Pasal 1365 KUH Perdata yang memuat ketentuan sebagai berikut:

"Every act against the law which consequently causes harm to others, obliges those who because of their wrongs cause harm to compensate."

Beberapa elemen dalam tindakan terhadap undang-undang adalah tindakan yang bertentangan dengan hukum, ada kesalahan, ada kerugian, dan yang terakhir adalah hubungan kausal antara kerugian dan tindakan. Kesalahan Notaris Umang Retno Ayu Melasari, S.H sebagai notari awam mengakibatkan ketidakpastian hukum dalam surat ikatan yang dibuatnya dan dapat mengakibatkan kerugian bagi Ms. Juju Adriyani di masa depan karena ketidakmampuan PT. Indomarco Prismatama sebagai parti ketika menandatangani surat ikatan itu. Sudah tentu kesilapan ini akan mengakibatkan keadaan surat ikatan asli dalam pasal 1338 Kanun Sivil jo. Perkara 38 UUJN tidak dipenuhi dan akta pajakan mempunyai bukti kekuatan di bawah tangan yang boleh membahayakan Ny. Juju Andriyani, yang menuduh PT. Indomarco Prismatama dan Notaris Umang Retno Ayu Melasari, S.H pergi ke mahkamah untuk membatalkan perjanjian itu.

Pembatalan perjanjian oleh mahkamah tentu saja menyebabkan Cik. Juju Andriyani akan mengalami kerugian, dan oleh itu, Cik Juju Andriyani berhak menyaman PT. Indomarco Prismatama dan Notaris Umang Retno Ayu Melasari, S.H. Berdasarkan Kamus Besar Bahasa Indonesia yang dipanggil Rugi adalah keadaan di mana seseorang tidak mendapat manfaat daripada apa yang mereka belanjakan.

Dikawal dalam Perkara 1238 Kanun Sivil Jo. Perkara 1243 Kod Awam dan Akta yang melanggar Undang-Undang sebagaimana yang terkandung dalam 
Volume 2 Nomor 2, Desember 2019 E-ISSN : 2655-7347

Perkara 1365 Kanun Sivil. Kerugian dalam Kod Awam boleh diperoleh daripada Default sebagai perjanjian dan tidak pernah ada persetujuan.

Jika sesuatu pihak cedera dengan membatalkan perjanjian itu, pihak yang cedera boleh meminta ganti rugi secara material dan tidak bersalah daripada pihak yang menyebabkan kerugian kerana syarat-syarat perundangan tidak dipenuhi.

Selaras dengan pengarang yang dinyatakan di atas, penulis berpendapat bahawa keputusan yang diambil oleh Mahkamah Tinggi Bandung kurang tepat berkaitan dengan kesahihan surat ikatan pajakan. Tanpa ketiadaan PT. Indomarco Prismatama dan kesilapan Notaris Umang Retno Ayu Melasari, S.H ketika menandatangani pajakan, unsur subjektif suatu perjanjian tidak dipenuhi dan mengakibatkan kesepakatan dibatalkan dan menjadi satu kekuatan bukti hanya di bawah tangan.

Perubahan dalam kekuatan bukti dari pajakan akan menyebabkan Cik Juju Andriyani dapat mengalami kerugian dan oleh karena itu, Juju Andriyani harus dapat menuntut pampasan atas akta yang tidak asli karena Notaris Umang Retno Ayu Melasari, SH, yang tidak melaksanakan posisinya sesuai dengan undangundang dan peraturan yang berlaku.

Seperti yang dinyatakan dalam Keputusan Mahkamah Tinggi Bandung Nomor 146 / Pdt / 2018 / PT.Bdg bahwa hakim menolak semua permintaan untuk merayu dan mengesahkan Keputusan Distrik Cibinong Nomor 25 / Pdt.G / 2017 / PN.Cbi yang menolak tuntutan mahkamah dan bukannya plaintif. Keputusan Hakim di Jawa Barat Keputusan Mahkamah Tinggi Nomor 146 / PDT / 2018 / PT.BDG. panel hakim menolak permintaan dari Juju Andriyani yang menuntut kembalinya rumah dan kompensasi dan terus menyatakan bahwa surat ikatan pajak 31 adalah sah dan tetap mengikat Pn. Juju Andriyani dan PT. Indomarco Prismatama.

Tetapi berdasarkan penjelasan di atas penulis mencadangkan bahawa perjanjian itu mesti batal dan tidak sah. Pembatalan perjanjian boleh mengakibatkan semua peristiwa yang kembali ke keadaan asalnya, dengan kata lain, perjanjian cukai tidak boleh dijalankan lagi kerana dianggap tidak berwujud. 
Volume 2 Nomor 2, Desember 2019

E-ISSN : 2655-7347

Oleh itu, PT. Indomarco Prismatama mesti segera mengosongkan objek sewa dan Ny. Juju Andriyani mesti mengembalikan pajakan kepada PT. Nilai cukai Indomarco Prismatama yang belum dibuat dan tidak membayar balik cukai yang telah dibuat mungkin dianggap sebagai ganti rugi untuk penggunaan PT. Indomarco Prismatama untuk kegunaan kedai milik Puan. Juju Andriyani.

\section{PENUTUPAN}

\section{A. Kesimpulan}

1. Pelanggaran yang dilakukan oleh Notaris Umang Retno, S.H. yang mengakibatkan kerugian bagi Juju Andriyani di mana akta sewa secara hukum cacat, sehingga sesuai untuk Notaris Umang Retno, S.H. bertanggung jawab sesuai dengan ketentuan dalam pasal 48 (3) dan Pasal 51 UUJN.

2. Pembuatan Akta Sewa Guna yang dilakukan antara PT Indomarco dan Ibu Juju Andriyani yang dibuat di hadapan Notaris Umang Retno, S.H. kekuatan pengacara yang dibatalkan oleh hukum cacat secara hukum yang mengakibatkan Juju Andryani mengalami kerugian di mana kekuatan pengacara yang telah rusak karena cacat hukum tidak lagi memiliki wewenang hukumnya.

3. Dalam melakukan sewa, Anda harus lebih memperhatikan. Jika sewa memang membutuhkan surat kuasa, maka surat kuasa harus hadir pada saat yang sama pada upacara penandatanganan.

\section{B. Saran}

1. Notaris perlu lebih berhati-hati ketika mendengar pernyataan para pihak dan lebih berhati-hati dalam memasukkan informasi dalam akta otentik dan jaminan harus yakin tentang kebenaran tanda tangan para pihak sebagai syarat pembuktian formal dalam pembuatan akta terpenuhi sehingga ketika ada masalah terkait dengan akta otentik dibuat, seorang notaris dapat menghindari dituntut. 
Volume 2 Nomor 2, Desember 2019

E-ISSN : 2655-7347

2. Notaris perlu meningkatkan kemampuan mereka di bidang hukum yang berkaitan dengan tanah dan lelang, karena saat ini notaris memiliki otoritas baru di bidang akta tanah dan akta perjanjian lelang serta meningkatkan kemampuan bahasa asing untuk menghadapi tantangan global dalam bentuk perdagangan bebas.

3. Bagi masyarakat, dalam hal membuat akta sewa harus lebih diperhatikan, lebih berhati-hati karena sebelum membuat perjanjian sewa harus terlebih dahulu memperhatikan yang Notaris ingin digunakan untuk tidak memilih Notaris yang salah yang menghasilkan perjanjian. dibatalkan demi hukum dan menyebabkan kerugian.

\section{REFERENSI}

\section{A. Buku}

Kie, Tan Thong. Book I: Notary Study, Several Subjects and Notary Practices,

Van Hoeve, Ichtiar Baru. (Jakarta: PT Ichtiar Baru Van Hoeve, 2000)

Mertokusumo, Sudikno. Mengenal Hukum Suatu Pengantar. (Yogyakarta: Liberty, 2003)

Soekanto, Soerjono. Introduction to Legal Research. (Jakarta: UI Press, 1981) 